\title{
Psychiatric care in the Brazilian context
}

\section{O cuidado psiquiátrico no contexto brasileiro}

Leandro Barbosa de Pinho ${ }^{1}$

LucianePrado Kantorski ${ }^{2}$

${ }^{1}$ Escola deEnfermagem,

Abstract This study seeks to present an updated discussion concerning psychiatric care in Brazil. It is based upon a historical review of psychiatric knowledge and practices within the Brazilian context and knowledge about the phenomenon of madness. It discusses the appearance of modern medical science as an area of knowledge designed for the treatment and comprehension of mental suffering. It also presents a discussion on psychiatric reform, stressing how it is a movement that seeks to redefinethesignificance of knowledgeand practices about the phenomenon of madness, by concentrating on the application of such knowledgeand practices in thepsychiatrichospital. This paper concludes with a brief critical reflection on prevailing mental healthcare in Brazil, singling out the potential and the difficulties faced within the scope of health policies and the day-to-day working life of professionals of the area. Key words M ental health, H ealth services, Community mental healthcare services
Resumo 0 presente estudo pretende fazer uma discussão atualizada acerca da assistência psiquiátrica no Brasil, tendo como base um resgate histórico dos saber es e práticas psiquiátricas no contexto brasileiro e a apropriação do fenômeno da loucura. Discute o surgimento da ciência médica moderna e da psiquiatria como área do conhecimento desi gnada ao tratamento e à compreensão do sofrimento mental. Também apresenta discussões acerca da reforma psiquiátrica, ressaltandoa como um movimento que vem ao encontro da ressignificação de saberes e práticas de intervenção referentes ao fenômeno da loucura, a partir da concentração desses saberes e práticas no hospital psiquiátrico. No final, realiza uma breve reflexão crítica sobre a assi stência em saúde mental no país na atualidade, constatando potencialidades e dificuldades enfrentadas no âmbito das políticas de saúde e do cotidiano do processo de trabalho dos profissionais da área.

Palavras-chave Saúde mental, Serviços de saúde, Serviços comunitários de saúde mental 
Reflections about thehistorical construction of psychiatric care

Understanding the madness phenomenon demands a complex of perspectives. We know that madness brings to theindividual a series of changes in their lifestyle. It alters the dynamic of one's network of relationships; imports functional limitations and behaviors; demands greater time, commitment, and availability not only in one's interpersonal links, but also in those with professionals that work in health care services and attend this specific clientele daily.

The dimension of psychiatric knowledge seems to compose a collective construction that in thefield of health care is related to diverseindividual, social, historical, and culturefactors. Rather, in order for us to better comprehend knowledge and the practice produced by psychiatry, it is necessary to report upon the remote conceptions about something yet more intriguing: the sickness-health process.

With the health care field as a reference, it is possible to affirm that medicine, being a profession within the area of health care, as been able to develop an entire body of knowledge and practices that attempt to materially reveal morecompletely the relationships of the world with man produce disease within a social context. It may be that this appropriation of the sickness-health process by medicine is one of the greatest contributions to our comprehension of phenomenon linked to the processes of becoming sick and of human life.

In the mental health field, the evolution of human knowledge has been paralleled with theoretical and practical explanations of interventions of the madness phenomenon. Since antiquity, humanity has sought manners and technologies to classify, group, and comprehend mental manifestations ${ }^{1}$. It was under the theoretical influence of Hippocrates and Galeno, in the Middle Ages that madness starts to be explained from the point of view of an organistic discourse. Thus it is considered as a state of imbalance within the human spirit and body. The Hippocratic and Galenic conceptions gaveorigin to behavioral and pneumatic conceptions of madness.

One could argue that the ascention of hippocratic-organistic knowledge, even contaminated as it was by a metaphysical influence (divine) typical of the ancient world, revolutionized thefield of knowledge and practices in mental health. Especially referring to madness, Hippocrates and Galeno opened the doors to unveiling the func- tional mechanisms of the human mind, which served as a foundation for increasing anatomical-physiological knowledge in the Renaissance era, as well as for ethiological-nosological rearrangements that constitute the psychopathological science that is seen today.

However, in the Middle Ages there was an accented ascension of Christian knowledge throughout the world. With that in mind, espe cially with Thomas of Aquinas and Augustine, the conception of madness returns to its theological aspects, but theretofore assuming a negative connotation. The fruit of a demonic presence upon the human body, it becomes seen as a permissiveness or the divine influence upon the individual's rational and emotional states. It is oriented as punishment, suffering, perturbation, and trial. This catholically influence theological vision inaugurates theperiod of thedemonic conception of madness ${ }^{1}$.

Madness has accompanied the development of society, at times exercising its power upon men, as happened during ancient times; and at times submitting to the power of psychiatry, as in the $18^{\text {th }}$ Century. Madness has the marks of an incomprehensible society in its historical constitution, which notwithstanding has treated madness from different angles, either seen as a dangerous object, a punishment, a sickness, an anomaly, a lesion, a problem, a challenge to conduct, or a perturbation of order. In short, a polissemy of feelings from which is extracted little or no completely coherent explanation. This demonstrates the vicissitudes of human expression and the contradictions of one's own thought, to the point of both inferiorizing man's knowledge and at the same time, provoking his fury.

Based on the sequestration of bodies for the study and exploration of diseases, it is in this period that mental medicine breaks away from its empirical findings in order to incorporateclinical, scientific knowledge that may be able to explain in its totality how, why, and when manifestations of madness occur.

In this manner, medicine, and in this conjuncture mental medicine, start to become characterized as the science of thebody, as a scientific practice, occupying diverse social extracts. If until the end of the $18^{\text {th }}$ Century medicine referred more to empirical data than the symptomatic manifestations of the subject in order to produce health, in the $19^{\text {th }}$ Century it begins to concern itself more with the normalization of the disease as an object of knowledge. In this way, it passes from the condition of medicine of the symptoms 
to medicine of bodily organs and tissues. Empirical medicine gives way to medicine of the "objects of its practice"2.

We understand that the concrete reality of medical-psychiatric production, at the sametime in which a "new knowledge" is born, consolidates a medical-dominate discussion which defends and disseminates the need for these practices. In this sense, non-permissive conduct of the asylum upon the insane inaugurates a new world psychiatric knowledge, designating room for treatment based upon a disciplinary pedagogic. This reality submits psychiatry to an advance in the comprehension system of mental behaviors. However, the contradiction in theinterior of psychiatric knowledge within this period seems clear to us. Discipline and continencehave yet to characterize themselves substantially as scientific knowledge concerning madness. This is due to the fact that were there to exist a nostal gic-etiological interest in this practice, madness would yet be comprehended as a manifestation of the reason and of the intellect, or in other words, the consequences of the passions of the human subject. We believe that there lacked something in order to consolidate this knowledge, something that could initiate the interlocution of the need for scientificating mental knowledge with the mental comprehension of theemotional processes as starting points of mental infirmaries.

Analyzing the contradictions and reflections upon the power that Pinel's moral treatment exercises upon the micro-space of madness manifestations, Goffman ${ }^{3}$ concludes that this gap has brought forth the opportunity for the creation of a moral career for the mentally ill. In the measurement that the person becomes institutionalized, their desires enter into conflict with the inflexibility of theinstitution. The patient sees her/ himself obligated to follow the conduct and routines imposed by thehospital, independent of the patient's will. Thus, thementally ill losetheir personal identity and without ties, without a "voice", without rights, without possibilities, becomes reduced to a "mortified-I". Within the hospital, this reality was responsible for generating grave psychological tensions and zones of conflict. To the author, these attitudes are typical of total institutions, which promote inactivity, and sluggishness in individuals upon encompassing the totality of their lives. They do not consider their immediate needs, physical expressions, psychologies, or future perspectives.

The Post-World War II period played a decisiverolein the criticism of the psychiatric hospi- tal structure. Thefirst reformist movements arose in order to take on the challenge of fighting the high levels of chronification of the sick and the social disabilities caused by the intern process. They were basically developed upon two theoretical sources: the reformist movements that arose within asylums, and those that arose outside of asylums. In the first, originated in the $50 \mathrm{~s}$ and 60s, onecan citetheTherapeutic Communities as developed by Maxwell Jones in England, which later spread across the United States, as well as French Institutional Psychotherapy. In the second, one can cite the Preventive Psychiatry as developed by Gerald Caplan and Sectoral Psychiatry in France. These last two modalities of care had significant influence in the proposals of I talian psychiatric reform in the 1970s, which was materialized in Law 180/78 4.6 .

The structural modifications in the mode of operating with mental health can have started from three important considerations?:

(1) The phenomenon of deinstitutionalizing psychiatric patients was occurring in several countries, even in contradictory ways and means. This population, previously confined in asylums, now lives among the community.

(2) The gradual acceptance that psychiatric care may be supplied in the community, instead of in large institutions. This results in the constitution of a "new approach". In other words, it results in the idea that community services can respond to the needs of the subjects in a way that is different from what is done in the psychiatric hospital.

(3) Thegrowth of sanitary conscience, which stimulated patients, family members, professionals in the area, and politicians to demand better life conditions and care for psychiatric patients. Theappearance of associations, self-help groups, and human rights groups could respond to a political need for constituting citizenship, in order to consider that thesubjects (individually and collectively) may count upon the "protection of health care", itself impossible to be achieved in psychiatric hospitals.

Psychiatry, for 200 years, seemed to have carried with it its contradictions as a field of knowledgeand practices. While it has attempted to fine tuneitself based on scientific medical knowledge, it has been constantly confronted with its own conceptions and fragilities, in a permanent "madness of itself". The result of such dis-reason, of such perturbation, or of the anormality, whatever concept one wishes to admit, psychiatry even today has not totaled its knowledge concerning 
what is madness. Psychiatry cannot yet fully explain it. Its working definition (partial and shortsighted) has been attained in the sense of describing the observablesigns of the mad patient, which arenot fully objective and organically explicable. For such a case, it has adopted a set of partnerships, destined to keep vigil upon the subject's behavior, his symptomatic group, the characteristic findings, and the segregation of differences. However, it seems to us that psychiatry has initiated a dive into its own arrogance, its own daydream in making its institutional discourse its only weapon of combat. Dis-reasoned psychiatry, that has tried to explain but even today little explains something definitively "inexplicable".

Evidently, all and any paradigm shift is a deconstruction process, which tends to provoke instabilities and can generateconflicts in thesense of evidencing resistance. It has been the case with psychiatry, for during approximately 200 years it has tried to found its performance through different knowledge which operates upon the mad patient and upon madness. For as much as in some countries the critical (re)construction of knowledgehasarrived with greater speed and new challenges, in other countries, such as Brazil, the specificity of mental health seems to be much morecomplex and intriguing. Wewill outlinethis topic in the following section.

Psychiatric care in the Brazilian context: from asylum practices to substituteservices

Thehistory of mental health in Brazil hasitsspecificities as well, but they do not impede that its birth was not contradictory or conflicting, permitting the initiation of distinct fields of knowledge and ambiguous practices, beyond the fact that it has been establishing itself little upon shared linearity and upon its digressions.

In the 19th Century, the conceptual mark of psychiatry was dominated by the conceptions of Pinel and Esquirol about mental illness, as well as by M orel's theory of degenerescence, which guided moral and pedagogical practices. In the $20^{\text {th }}$ Century, psychopathology becomes influenced by the predominance of the Kraepelin's German organistic current, which introduced the concept of anormality and fed the non-scientificity of these moral practices, which appeased and disciplined but did not explore the nature of the mental problem. M orel's and Kraepelin's conceptions of madness were determinant for amplifying the psychiatric fields into social areas, when everything that could be classified as antisocial or undisciplined (alcoholics, drug users, those with syphilis, criminals, lepers) was considered an "anormality", together with the analysis of its physiopathological dispositions ${ }^{8}$.

Another important question in order to bring to light the contradictions within Brazilian psychiatry, has been the contemplation of three distinct theoretical models of mental disease, though they were born practically together in the beginning of the $20^{\text {th }}$ Century and continueto compete among themselves. The first, as already commented, is the "organistic model", promoted by Juliano Moreira, Franco da Rocha, and Teixeira Brandão. The second is the "psychological model", which contemplates the analysis of psychic life (as inspired by Freud and Lacan) and introduces the concept of neurosis, based on an amplified comprehension - albeit yet centralized of the psychic structures of the individual. The third theoretical model for mental disease is expressed in the "sociological model", which separates madness towards the area of social medicine. It is a direct reflection of the conditions of society and thus, needs to be modified 8 .

Thetheoretical body which made possiblethe explosion of psychiatry towards the social seems to bring to light the particularities of a science that has sought to make the various expressions of madness true, not as human suffering, but as the nature of an organic alteration that has manifested itself in transgressive and abnormal behavior. The fight against disorderly conduct and its denial by means of a triple debate (organisticpsychological-sociological) may, as well, be reflections of the manner in which Brazil has organized itself. Thus it is like the complex mode in which psychiatric knowledge and practices have at the same time approached one another and distanced themselves from each other within the Brazilian psychiatric context.

The period from 1900 to 1930, called the Old Republic ("República Velha"), is marked by a complex process of sectoral policy constitution that were oriented by a capitalist political-economic system. In capitalism, increasing the needs of the productive context many times would lead to health as an "annex", without the political due dilligence offered it. Such a fact occurred as a re sult of the influence of the agro-export model and the dependent coffee growers, which in turn promoted health actions based on an intervenistcampaign model in order to contain the proliferation of endemic-epidemic illnesses that prejudiced international negotiations ${ }^{9-11}$. 
In the context of psychiatric care, the Old Republic period is marked by the construction of hygienic and eugenic psychiatric knowledge, concentrated upon the sanitary premises of social spaces. According to the authors, hygiene as a new conception of health, is a result of social medicine and the sanitarist-campaign model. Prior to that period $n$ Brazil, one would die of an ample variety of diseases, such as smallpox, yellow fever, malaria, typhoid, tuberculosis, and leprosy, all more easily disseminated by the accelerated non-planned urbanization. This period of "social disorder" created a distorted impression that the city, and not the process of concentrating man into these urban spaces. As a result, the cities needed to be "hygiened", and through them the human body ${ }^{12}$.

This distorted tendency of hygienic psychiatric knowledge started to reinforce the privatist proposals that had developed as of 1950. It was all possiblethanksto developmental philosophy, maintained through the period of themilitary overthrow of 1964, as well as through theperiod of technological advance. According to thismovement, thetechnological advance would provide benefits to the population. As such, Brazil begins its process of economic internationalization, increasing investment in areas considered to bepriorities in order to remain active in external markets ${ }^{13}$.

In the environment of psychiatric care, the privatization and the hospital-centered tendencies permitted the expansion of theimmense" $\mathrm{Re}$ treat Hospitals" ("Hospitais-Colônia") and the gradual reduction of investment in the ambulatorial and non-hospital network, which stimulated yet further thechronification process of the patients. For example, from 1965 to 1970, it was possible to verify the steady flow of these patients towards the private sector, when the number of interned patients went from 35,000 to 90,000 by the end of theperiod, with thepatients many times staying morethan three months. The therapeutic practices were summarized in local activities, kept under organistic sponsorship ${ }^{5}$.

This reality only will become criticized and transformed with the movements of sanitary reform and psychiatric reform, both initiated at the end of the 1970s. Sanitary reform was characterized asan intense, complex, highly contested movement which resulted from the insatisfaction of the management of health care policies in Brazil. The movement involved unions, intellectuals, health care workers, and users of the services provided a grand structural reconsideration in the sense that health care has since become seen as a "social right" for everyone. The entire debatewas generated in a period which followed the fall of the military dictatorship at the end of the 1970s, with the sense of redemocratization of the country and theneed for decentralizing heal th care services in order to attend all those who initially had been excluded from the system ${ }^{14-15}$.

For the integral members of the movement, Brazilian sanitary reform urged for the necessity of reorganizing the entire network of health care services, with a construction of a national system that could contemplate the diverse demands and needs of the subject. H owever, the theoretical and also political transition from one centralized system to another was slow and gradual. Basic attention was elevated with the constitution of PIASS (Internalization of H ealth Care and Sanitary Actions Program - "Programa de Interiorização das Ações de Saúdee Saneamento") in 1976, and with the Alma-A ta Conferences, as well as with Adelaide (1986). Two other equally relevant events for the consolidation of sanitary ideas refer to the $8^{\text {th }} \mathrm{N}$ ational $\mathrm{H}$ ealth Care Conference (1986) and theinstallation of the $\mathrm{N}$ ational Legislative Assembly ("Assembleia Nacional Constituinte"), which made it possible to construct the basic theories and methodologies of the National Public H ealth Care System ("Sistema Ú nico de Saúde") and its materialization in the Brazilian Constitution of $1988^{16}$.

Another decisiveinfluencein accelerating the restructuring of psychiatric carein Latin America was the Declaration of Caracas. Originated as part of the Regional Conference held in Venezuela on N ovember $14^{\text {th }}, 1990$, it was made possible because of support from the Pan-American $\mathrm{H}$ ealth Organization, as well as the World $\mathrm{H}$ ealth Organization (PAHO/WHO) and resulted from the participation of delegates, organizations, associations, legislators, and jurists. The declaration itself concentrated more upon discussions surrounding the hegemonic role of the psychiatric hospital and itslimited therapeutic efficiency, as well as gave incentives for redefining the curriculum of $M$ ental $H$ ealth and Psychiatric courses in the region's undergraduate programs in health sciences ${ }^{17}$.

The substitute services which have revealed themselves as proposals for reorientation of hospital-centric psychiatric care make up part of a re-invented reality, incorporating themselves in the political locus as decentralizing strategies for mental health care. They also comprehend the materialization of the sanitary concepts and of the movement for psychiatric reform, oriented 
by democratic Italian psychiatry. Psychiatric re form arises in the Brazilian context more in the form of a structural redefinition of services, for it contemplates an "epistemological rupture" from hegemonic knowledge and practices that projected in their discussion of the mentally ill, a sociocultural load of years of contradictory, inverted values, many times hidden for private interests.

Thinking within this context begins a transaction of the Bill for Law 3.657/89, which legislates the rights of person with a mental illness. The bill in question was modified and approved in the form of Law 10,216 (Lei $n^{\circ} 10.216$ ), on April $6^{\text {th }}, 2001$, after 12 years of debate on the floor. However, in this period of discussion, some States of Brazil had al ready included in their constitutions of local policy for mental health, and the $\mathrm{M}$ inistry of $\mathrm{H}$ ealth madeavailablenormative instruments in order to instruct and guide the mental health network in the country ${ }^{18}$. The Psycho-social Care Centers (Centros de Atenção Psicossocial - Caps) are currently found within this context.

The conception of a service that attends the principles of the loco-regional and decentralized orientation (such as Caps), beyond the material possibility of producing "communicative subjects" and those who intervenein reality seems to be one of the advances of the Brazilian psychiatric reform. We understand that the birth of these substitute services is revealed as a concrete characteristic which intends to offer a "dialectic character" to psychiatric care, possibly capable of managing the "asylum vices" and its institutionalized discourse in order to change, to insert, to assist, to include, to welcome, and to care.

Final reflections concerning the psychiatric reform movement and psychiatric care in Brazil

New knowledgein psychiatry, which expands the field to the social circle, has a reformist character, and has socialized and given incentives for the redimensioning of knowledge and practices surrounding madness, seems to include along with it a scenario of challenges, assimilations, and in the same fashion contradictions, above and beyond its tendencies for a paradigmatic transformation. A (re)construction of knowledge and practices, a theoretical opening in order to transit towards new horizons, but which demands from us a critical reflection of our care reality. Such reflection goes beyond the (de)construction of ancient knowledge and practices concerning the patient and his/her madness, but incorporates the rhetoric of sharing instead of verticalization and complementarity instead of absolutism. It is a new material dimension, in which the patient with madness, previously seen as a dominion of others, currently learns to conquer his/ her autonomy; self-domination that can be "treated", of course, but principally be "treated" and "cared".

We understand that caring for human beings in the context of psychiatric reform contemplates complex knowledgeand practices that are identified with our complex manner of being, acting, thinking, and "being" inserted into the world. Whether to alleviate suffering, to show one's self to bepresent, or to exercise the ability to "care" for fellow humans, care becomes a dimension that contemplates part of theindividual's actions, part of his/her true "being-in-the-world". In other words, it becomes part of ourselves and our manner of living ${ }^{19,20}$. In dealing with mental health, to care is "to diminish distancing"21,22; it is to understand theliving process, to mobilize resources and strategies and to comprehend the complexity of themanifestations of madness ${ }^{23,24}$. It is, in the same way, to share life projects, to restore affective ties and to stimulatethe potential the human being in all its multidimensionality.

In this context, psychiatric reform can reinvindicatea new space for the construction of subjects, instead of remain hostage to an all-encompassing logic, parceled from life. It urges for the need to overcome this social division, this contradiction, in order to establish a social commitment with those who are excluded and to suspend the modus asylusin operating with theindividual who was expropriated from him/herself. In order to do this, it is necessary to redimensionize our view of madness, to produce a humanized, inventive, caring "psychosocial mode" 25 of knowing, being and doing; one that cultivated life, subjectivities, and that all these things can make up part of the treatment "of, in, and through" the daily lives of people, "in" their existential territories, "in" their communities.

However, when we speak of psychiatric care, more than "reducing" health care to a mere theoretical-conceptual dimension, we must find manners to "produce" health care. In order to do this, there must be commitments and responsibilities established in the macro and micro-structural contexts. Advertising here for the presence of temporal spaces and their singular historic movements, the production of health care must 
not only care for the clinical signals, symptoms, or findings, which could respond to the more immediate needs of knowledge in solidification. In contemporary life, as much thinking in terms of health care knowledge as in practices, to produce health care is to "go beyond", to comprehend its historical-structural evolution, to beable to negotiate socially, to beable to mobilize political resources and strategies, but also to be able to enter into the intersubjective context of the subject, to learn daily to respect singularities and particularities- one's culture, relationships, mode of collective organization, as well as problems, limitations, difficulties, and expectations before the condition of becoming sick and suffering.

In the context of Brazilian psychiatric care, madness, as a dimension of human life and the sickness-health process, must not be reduced to a singleoperating knowledge, as has happened in psychiatry for the past 200 years. Beforethestructural transformations of national policies for mental health, based on a reformist movement, it is necessary that we are attentive to the comprehension of multiple determinants (bio-psycho-socio-cultural) that influence the mode in which we organize ourselves in society and understand manifestations in the sickness process.

Even beforethepossibility for cultivating a new paradigm, discussions concerning psychiatric reform yet need to advance in the Brazilian context. One of the most important factors, possibly the most visible, is in the very creation of substitute services for the asylum. In Brazil, as of December of 2006, there were 1,000 Caps implanted, representing an increase of approximately $36 \%$ in comparison with the same period the previous year ${ }^{26}$. However, the proportion of territorially-based services is still small if compared with the country's geopolitical area. The State of Amazonas (greatest in the Republic) presented merely one functioning Caps in 2005, while Sergipe (smallest in the Republic) made use of 15. The Southeast region for example (the most populous) in the same period presented a proportion of merely 0.34 Caps per 100,000 habitants, while the Southern region with its population threetimessmaller than that of the Southeast region, presented an index of 0.43 Caps per 100,000 habitants $^{27}$.

Another factor that deserves note in discussion surrounding psychiatric reform is the reduction of the simple opening of substitute services. Brazilian mental health care policy has given incentivefor theopening of Caps, but thought little about the consequences of this indiscriminant opening throughout the country. As such, the implementation of services has not only reduced the ample repertoire of therapeutic resources (caring for, assisting, welcoming, listening, including), as well as reduced the complexity of psychiatric reform to an administrative and bureaucratic reorganization of its services. In summary, the reform has become that which "modernizes" and occurs within existing Caps not outside of them ${ }^{28}$.

Another question that has separated the dialectic character from Brazilian psychiatric reform is not found in the macro-structural context of public policies, but in the micro-structural context. Rather, it is in the daily life of the work of its professionals. The professionals' daily lives, different reformist practices are mixed with "antireformist" practices. This occurs becausethe professionals continue to center themselves on the object of their work in "sickness" when they should be concentrated on the object "subject". Thus emancipatory practices, such as incentive towards liberty, the right to one's voice, to citizenship, to autonomy of the individual in mental suffering live with practices that are destined to disciplinary control, to guardianship, to exclusion from families, to normalization of behavior, to centralization of power 29,30 .

In this sense, it is not enough to welcome the mad patient as if wewere to "transform", nor even to extinguish the asylums in order to say that we have "made reforms", for the true psychiatric reform is born of the reinvention between body and language, between subjectivity and exteriority, between duty and social, between human and inhuman, between perception and the invisible, between desire and thought. In order to effectively deconstruct, it is necessary to deconstruct our rationality to the point of transiting a little in madness, to exerciseovercoming dialect. However, none of this would be enough, if, even freeing the mad from the asylums, we were to keep another asylum intact, mental, in which we confine the disreason and what seems to be "inoffensive" 31 .

Internal and external asylums that initially, need to be taken apart at great cost, become a daily exercise for professionals, users, communities, and society. Brazilian psychiatric reform, however recent, is hereto bepracticed, but needs to beconstantly discussed, problematized, re-signified. In order to understand the complexity of madness, it isnecessary to evokethe dialectic character in its essence. To think of its potentialities, its difficulties, its limitations in space, in its internal and external resistances, in its conformist postures, in what we want for ourselves and for 
others, in what we want for the country in terms of health care. No reform is born with the objective to (simply) overcome the previously criticized model. It is also born as a critique and to be criticized. It is possible to do something different; it is only necessary that we are willing to change our own postures, concepts, and our reality.

\section{Collaborations}

LB Pinho was the responsible for the design, the literaturereview and thewriting; LP Kantorski participated in thediscussion and the final revision.

\section{References}

1. Pessotti I. Os nomes da loucura. São Paulo: Editora 34; 1999.

2. Foucault M. O nascimento da clínica. Rio de Janeiro: Forense Universitária; 2004.

3. Goffman E. M anicômios, prisões e conventos. São Paulo: Perspectiva; 1990.

4. Kantorski LP. Mental health care in Brazil. J Psychiatr M ent Health Nurs 2002; 9:251-253.

5. Resende H. Política de saúde mental no Brasil: uma visão histórica. In: Tundis SA, Costa NR, organizadores. Cidadania e loucura: políticas de saúde mental no Brasil. Petrópolis: Vozes; 2001. p. 41-71.

6. Girolamo G, Cozza M. The Italy psychiatric reform. Int J Law Psychiatry 2000; 3-4:197-214.

7. Saraceno B, Frattura L, Bertolote JM. Evaluation of psychiatric services: hard and soft indicators. In: World Health Organization (WHO), organizador. Innovative approaches in service evaluation. Geneva: WHO; 1993. p. 35-52.

8. Portocarrero V. Arquivos da loucura: Juliano M oreira e a descontinuidade histórica da psiquiatria. Rio de Janeiro: Editora Fiocruz; 2002.

9. Campos GWS. Reforma da reforma: repensando a saúde. São Paulo: Hucitec; 1992.

10. M erhy EE. Saúde pública como política: um estudo de formuladores de políticas. São Paulo: Hucitec; 1992.

11. Elias PE. Estado e saúde: os desafios do Brasil contemporâneo. São Paulo Perspec 2004; 18(3):41-46.

12. Boarini $\mathrm{ML}$, Yamamoto $\mathrm{OH}$. Higienismo e eugenia: discursos que não envelhecem. Psicologia Rev 2004; 13(1):59-72.

13. Ribeiro PRM. Saúde mental no Brasil. São Paulo: Arte \& Ciência; 1999.

14. Cohn A, Nunes E, Jacobi PE. A saúde como direito e como serviço. São Paulo: Cortez; 1999.

15. Mendes EV. Uma agenda para a saúde. São Paulo: Hucitec; 2006

16. Fleury S. A reforma sanitária e o SUS: questões de sustentabilidade. Cien Saude Colet 2007; 12(2):307317.

17. Brasil. Ministério da Saúde. Legislação em saúde mental. Brasília: Ministério da Saúde; 2004.

18. Nicácio M FS. U topia da realidade: contribuições da desinstitucionalização para a invenção de serviços de saúde mental [tese]. Campinas (SP): Universidade Estadual de Campinas; 2003.

19. Waldow V. 0 cuidado na saúde: as relações entre o eu, o outro e o cosmos. Petrópolis: Vozes; 2004.
20. Boff L. Saber cuidar: ética do humano, compaixão pela terra. Petrópolis: Vozes; 1999.

21. Perraud S, Delaney KR, Sabelli-Carlson L, Johnson $M E$, Shephard R, Paun O. Advanced practice psychiatric mental health nursing, finding our core: the therapeutic relationship in $21^{\text {st }}$ century. Perspect Psychiatr Care 2006; 42(4):215-226.

22. Silverstein CM. Therapeutic interpersonal interactions: the sacrificial lamb? Perspect Psychiatr Care 2006; 42(1):33-41.

23. Amarante P. Novos sujeitos, novos direitos: o debate em torno da reforma psiquiátrica. Cad Saude Publica 1995; 11(3):491-494.

24. Cleary M. The challenges of mental health care reform for contemporary mental health nursing practice: relationships, power and control. Int J M ent Health Nurs 2003; 12:39-147.

25. Costa-Rosa A, Luzio CA, Yasui S. Atenção psicossocial: rumo a um novo paradigma na saúde mental coletiva. In: Amarante P, organizador. Archivos de saúde mental e atenção psicossocial. Rio de Janeiro: Nau Editora; 2003. p. 13-44.

26. Brasil. Ministério da Saúde. Saúde mental no SU S: informativo da saúde mental. Brasília: Ministério da Saúde; 2006.

27. Brasil. Ministério da Saúde. Saúde mental no SU S: informativo da saúde mental. Brasília: Ministério da Saúde; 2005.

28. Amarante P. A (clínica) e a reforma psiquiátrica. In: Amarante $P$, organizador. Archivos de saúde mental e atenção psicossocial. Rio de Janeiro: Nau Editora; 2003. p. 45-66.

29. Oliveira AGB, Nessi N. Superando o manicômio? Desafios na construção da reforma psiquiátrica. Cuiabá: Editora UFM T; 2005.

30. Wetzel C. Avaliação de serviço em saúde mental: a construção de um processo participativo [tese]. Ribeirão Preto (SP): Universidade de São Paulo; 2005.

31. Pelbart PP. Manicômio mental: a outra face da clausura. In: Lancetti A, organizador. Saúdeloucura. São Paulo: Hucitec; 2001. p. 131-138.

Artigo apresentado em 15/03/2008

Aprovado em 19/01/2009

Versão final apresentada em 22/02/2009 